\title{
Shading on Yield and Quality of Lettuce Cultivars in Semiarid Conditions
}

\author{
Claudio de O. Costa Júnior ${ }^{1}$, Roberto Cleiton F. de Queiroga ${ }^{1}$, Caio da S. Sousa ${ }^{2}$, Cidia Cilene de Figueiredo ${ }^{3}$, \\ Evandro Franklin de Mesquita ${ }^{2}$, Francisco Hevilásio F. Pereira ${ }^{1}$, Sebastião de O. Maia Júnior $\mathrm{II}^{4}$, \\ Jackson de M. Alves ${ }^{2}$, Alex Serafim de Lima ${ }^{2}$ \& Albanisa P. de Lima Santos ${ }^{1}$ \\ ${ }^{1}$ Center for Agro-Food Science and Technology, Federal University of Campina Grande, Pombal, Paraíba, \\ Brazil \\ ${ }^{2}$ Department of Agrarian and Exact Sciences, State University of Paraíba, Catolé do Rocha, Paraíba, Brazil \\ ${ }^{3}$ Institution of Higher Education Cajazeiras, Cajazeiras, Paraíba, Brazil \\ ${ }^{4}$ Academic Unit of Agricultural Engineering, Federal University of Campina Grande, Campina Grande, PB, \\ Brazil \\ Correspondence: Sebastião de O. Maia Júnior II, Academic Unit of Agricultural Engineering, Federal University \\ of Campina Grande, Campina Grande, Paraíba, Brazil. Tel: 55-083-996-361-429. E-mail: \\ juniormaiagrari@hotmail.com
}

Received: February 9, 2019

Accepted: May 25, $2019 \quad$ Online Published: July 31, 2019

doi:10.5539/jas.v11n11p162

URL: https://doi.org/10.5539/jas.v11n11p162

\begin{abstract}
Lettuce is a crop originating from temperate climate, and for this reason, when cultivated in semiarid region, characterized by high luminosity and temperature, major losses in productivity and quality occur. The objective of this work was to evaluate the influence of different levels of shade on yield and quality of lettuce cultivars in semiarid conditions. The experiment was conducted under field conditions at the Human and Agricultural Sciences Center at State University of Paraiba, Brazil, in randomized blocks with parcels divided into $4 \times 4$ factorial space, and four repetitions. The parcels received different shading levels $(0,30,50$ and $70 \%)$ with black polypropylene screen and sub parcels by lettuce cultivars: 'Americana Irene', 'White Boston', 'Regina de Verão' and 'Green Salad Bowl'. The shading promoted higher performance in height, stem diameter, root length, $\mathrm{pH}$ and dry mass of lettuce plants when compared to those grown in the open-air, being the shading of $70 \%$ the more efficient. The 'Americana Irene' cultivar was distinguished in terms of plant height, foliage area, leaves dry mass and soluble solids, independently from the cultivation environment. With the shading, this cultivar improved the aerial shoot-root ratio and root dry mass.
\end{abstract}

Keywords: Lactuca sativa L., dry mass, luminosity, photoinhibition

\section{Introduction}

Lettuce (Lactuca sativa L.) is a leafy vegetable that presents broad adaptation to several environments, low production cost, low susceptibility to plague and diseases, easy handling, short cycle, high productivity and economic profitability, being one of the most cultivated specie through Brazilian regions (Araújo Neto et al., 2012).

This oleraceous originates from temperate climate countries, which makes its cultivation in tropical climates a challenge for producers, due to the low productivity and bad quality of leaves caused by increased luminosity and temperature (Blind \& Filho, 2015; Guerra et al., 2017).

Excess of solar radiation may cause direct damage to plants, affecting the $\mathrm{CO}_{2}$ assimilation through the photosynthetic process, known as photoinhibition, very common in plants with photosynthetic mechanism $\mathrm{C}_{3}$, such as lettuce (Fu et al., 2012; Guerra et al., 2017). Furthermore, the increase in radiation tends to increase air temperature, negatively interfering in the crop production with the decrease in plant grow, yield and quality (Fu et al., 2012; Ilić \& Fallik, 2017). Temperatures above $20{ }^{\circ} \mathrm{C}$ stimulate bolting, which is accelerated with increased temperatures and even more critical when associated to long days, resulting in anticipation of the harvest and low-quality plants (Santi et al., 2010). On the other hand, excessive shading may present a cycle 
extension, etiolation of the plants and productivity reduction, arising from the reduction in photosynthetic flow (Blind \& Silva Filho, 2015).

In semiarid regions, where environments present high luminosity and temperature, the culture cannot grow and develop according to its maximum genetic potential. Under such conditions, plants tend to shorten the cycle, reducing in addition the quality, while yielding fibrous, small and bitter leaves (Luz et al., 2009).

These factors can be minimized by using shading screens, which work to reduce the deleterious effects of high radiation and temperatures (Silva et al., 2015; Pinheiro et al., 2016), providing a microclimate appropriate to the development of the crop (Kotilainen et al., 2018). In this study, we evaluated the effect of dry matter accumulation (Pinheiro et al., 2016; Guerra et al., 2017).

The adaptation to different environments of cultivation varies according to the genetic potential of each group or cultivar, being essential knowledge about the different shading conditions (Guerra et al., 2017). A few researchers have reported the effect of shading screens in lettuce crops, such as Fu et al. (2012), Sales et al. (2014) and Gonçalves et al. (2017), as well as the behavior of different cultivars, as demonstrated by Guimarães et al. (2011), Souza et al. (2013) and Blind and Silva Filho (2015). However, studies involving simultaneously different shading levels and lettuce cultivars are scarce, mainly those involving different groups.

The objective of this work was to evaluate the influence of different levels of shade on yield and quality of lettuce cultivars in semiarid conditions.

\section{Material and Methods}

The experiment was conducted under field conditions, at the Human and Agricultural Sciences Center at State University of Paraiba, Campus IV, in Catole do Rocha county, Paraiba State, Brazil (6 $20^{\prime} 38^{\prime \prime}$ S 37 $47^{\circ} 44^{\prime \prime}$ W; altitude $270 \mathrm{~m}$ ), in the period from July to September 2017.

According to Köppen classification, the climate of the region is BSw'h', characterized by a hot semi-arid, with two distinct seasons, a rainy one with irregular precipitation and a dry season. The annual average rainfall is 800 $\mathrm{mm}$, the average temperature is $27^{\circ} \mathrm{C}$ and the rainy season concentrates from February to April.

Soil is classified as Eutrophic Fluvic Neosols (Santos et al., 2013), not saline and gently flat terrain. Soil samples were collected in the 0-20 cm depth layer and analyzed following the methods adopted by Embrapa (1997), whose characteristics are shown in Table 1.

Table 1. Chemical and physical characteristics of the soil used for the experiment. Catole do Rocha-Paraiba, Brazil, 2017

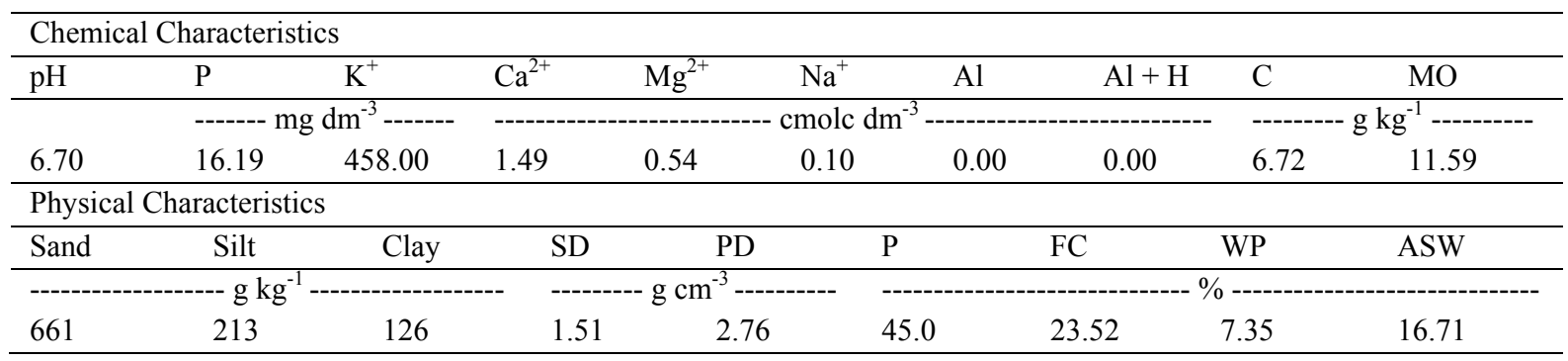

Note. $\mathrm{MO}=$ organic matter; $\mathrm{SD}=$ Soil Density; $\mathrm{PD}=$ Particles Density; $\mathrm{P}=$ Soil Porosity; $\mathrm{FC}=$ Field Capacity; $\mathrm{WP}=$ Wilting Point; ASW $=$ Available Soil Water.

The water used in the experiment was also analyzed (Table 2).

Table 2. Chemical characterization of the water used in the experiment. Catole do Rocha-Paraiba, Brazil, 2017

\begin{tabular}{llllllllllll}
\hline $\mathrm{pH}$ & $\mathrm{CE}$ & $\mathrm{SO}_{4}^{-2}$ & $\mathrm{Mg}^{+2}$ & $\mathrm{Na}^{+}$ & $\mathrm{K}^{+}$ & $\mathrm{Ca}^{+2}$ & $\mathrm{CO}_{3}^{-2}$ & $\mathrm{HCO}^{-3}$ & $\mathrm{Cl}^{-}$ & $\mathrm{RAS}$ & Classification \\
\hline 6.90 & 0.84 & 0.18 & 1.48 & 6.45 & 1.21 & 2.50 & 0.00 & 10.75 & 7.00 & 4.57 & $\mathrm{C}_{2} \mathrm{~S}_{1}$ \\
\hline
\end{tabular}

Note. $\mathrm{EC}=$ Electrical conductivity of water; $\mathrm{EC}$ was determined in the Soil and Water Analysis Laboratory from the Federal University of Paraiba, Campus II, Areia, Paraiba, Brazil; $\mathrm{C}_{2} \mathrm{~S}_{1}=$ water with medium salinity and low sodicity risks. 
The experimental design was in randomized blocks, in subdivided parcels in $4 \times 4$ factorial space, with 4 replications. The parcels received different shading levels $(0,30,50$ and $70 \%)$ with black polypropylene screen and sub parcels with lettuce cultivars corresponding to different groups: 'Americana Irene' (Cabbage/Head Lettuce), 'White Boston' (Butterhead Lettuce), 'Regina de Verão' (Leaf Lettuce) and 'Green Salad Bowl' (Mimosa), to a total of 16 treatments and 64 experimental units.

Seeding was performed in 162-cell polystyrene trays, containing own commercial substrate to produce vegetable seedlings. Four seeds per cell were seeded at a depth of $0.5 \mathrm{~cm}$, where such remained in a greenhouse until transplantation. Thinning was performed ten days after seeding, leaving just one plant per cell.

The preparation of the experimental area in the field was carried out by plowing followed by harvesting. The beds were created 1.25 meters wide, 13 meters long and 0.20 meters high. Bovine manure was incorporated in the beds to raise the contents of organic matter from 1.15 to $3 \%$, according to the formula proposed by Bertino et al. (2015). The characterization of the cattle manure used in the beds is shown in Table 3.

$$
\mathrm{M}=\frac{(\mathrm{DMI}-\mathrm{DMO}) \times \mathrm{VS} \times \mathrm{SD} \times \mathrm{MDM}}{\mathrm{CMM}}
$$

Where, M: amount of cattle manure to be applied by seedbed (g); DMI: organic matter dosage to be increased in soil $\left(\mathrm{g} \mathrm{kg}^{-1}\right)$; DMO: organic matter dosage existing in soil $\left(\mathrm{g} \mathrm{kg}^{-1}\right)$; VS: volume of seedbed; SD: soil density; MDM: moisture of dry cattle manure; CMM: content of organic matter existing in manure $\left(\mathrm{g} \mathrm{kg}^{-1}\right)$.

Table 3. Chemical characterization of the cattle manure used as organic matter source for the experiment. Catole do Rocha-Paraiba, Brazil, 2017

\begin{tabular}{|c|c|c|c|c|c|c|c|c|c|c|c|c|}
\hline $\mathrm{N}$ & $\mathrm{P}$ & $\mathrm{K}^{+}$ & $\mathrm{Ca}^{2+}$ & $\mathrm{Mg}^{2+}$ & $\mathrm{Na}^{+}$ & $\mathrm{Zn}^{2+}$ & $\mathrm{Cu}^{2+}$ & $\mathrm{Fe}^{2+}$ & $\mathrm{Mn}^{2+}$ & OMS & $\mathrm{OC}$ & $\mathrm{C} / \mathrm{N}$ \\
\hline & 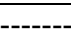 & ------- & $\mathrm{kg}^{-1}$ & 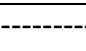 & ------ & & ----- m m & $\mathrm{kg}^{-1}$ & ------ & ------ g & $\mathrm{g}^{-1}$------ & \\
\hline 12.76 & 2.57 & 16.79 & 15.55 & 4.02 & 5.59 & 60.00 & 22.00 & 855.00 & 325.00 & 396.00 & 229.70 & $18: 1$ \\
\hline
\end{tabular}

Note. $\mathrm{OMS}=$ Organic Matter in Soil, $\mathrm{OC}=$ organic carbon, $\mathrm{C} / \mathrm{N}=$ carbon/nitrogen ratio.

Transplanting occurred at 20 DAS (days after sowing), when the plants already had two pairs of leaves. For the cultivation was adopted the spacing of $25 \times 25 \mathrm{~cm}$, totaling 16 plot plants ${ }^{-1}$. Each plot was covered with the shade screen corresponding to the treatment, under wood structures with $50 \mathrm{~cm}$ in height, while the treatment at $0 \%$ shading (outdoors) received no shade cover.

Plant irrigation was performed on a daily-basis using the localized irrigation method, according to the evapotranspiration of the crop-Etc $\left(\mathrm{mm} \mathrm{day}^{-1}\right)$, adopting the drip irrigation system. Calculation was performed based upon the reference evapotranspiration $\left(\right.$ Eto, $\mathrm{mm} \mathrm{day}^{-1}$ ), estimated by tank Class $\mathrm{A}$ and corrected by the $\mathrm{Kc}$ of the crop according to the plant development stage, obtaining the consumptive usage (Uc) considering the percentage of wet area $(\mathrm{P})=100 \%$. With that, for the purposes of calculating the daily liquid irrigation plates $(\mathrm{LLD}=\mathrm{ETc})$, it was obtained LLD $=\mathrm{Uc} \times \mathrm{P} / 100\left(\mathrm{~mm}\right.$ day $\left.^{-1}\right)$; the coefficient of the tank Class A $(\mathrm{Kp})$ was 0.75 , and the coefficient for variable cultivation according to the stage of the culture $(\mathrm{Kc})$, where from $0-8$ days it was considered 0.30 ; from $9-16$ days 0.52 ; from $17-24$ days 0.93 ; from $25-33$ days 0.87 ; and from $34-38$ days 1.02 according to Santana et al. (2016).

Weeding was performed manually according to need of the crop.

At 15 and 30 DAT (days after transplantation), the climate conditions of the experimental area were evaluated. Air temperature was evaluated with the aid of a Thermo Hygrometer placed below the shading screens and in open-air, performed at 9 a.m. Similarly, soil temperature was evaluated on the surface and in layers from 0-10 $\mathrm{cm}$ and 10-20 cm using a digital thermometer (Incoterm) at 9 a.m. for all shading treatments and control. Incident radiation was evaluated using a Ceptometer, and measurements were also performed at 9 a.m. (Table 4). 
Table 4. Values for air and soil temperature, and incident radiation in lettuce cultivation under different shading levels at 15 and 30 days after transplantation. Catole do Rocha-Paraiba, Brazil, 2017

\begin{tabular}{|c|c|c|c|c|c|c|}
\hline \multirow{2}{*}{ SL $(\%)$} & \multirow{2}{*}{$\mathrm{T}$ air $\left({ }^{\circ} \mathrm{C}\right)$} & \multicolumn{2}{|c|}{ Radiation $\left(\mathrm{MJ} \mathrm{m}^{-2}\right.$ day $\left.^{-1}\right)$} & \multicolumn{3}{|c|}{ Soil Temperature $\left({ }^{\circ} \mathrm{C}\right)$} \\
\hline & & ass $^{1}$ & $\mathrm{bss}^{2}$ & $\mathrm{sl}^{3}$ & $10-20 \mathrm{~cm}$ & $20-30 \mathrm{~cm}$ \\
\hline \multicolumn{7}{|l|}{$15 D A T$} \\
\hline 0 & 38.05 & 2393.50 & - & 50.50 & 29.81 & 28.69 \\
\hline 30 & 35.75 & 2256.00 & 1453.00 & 39.75 & 28.88 & 27.50 \\
\hline 50 & 35.50 & 2062.20 & 1148.20 & 39.25 & 28.00 & 27.00 \\
\hline 70 & 34.25 & 2218.50 & 831.50 & 33.31 & 26.81 & 26.56 \\
\hline \multicolumn{7}{|l|}{$30 D A T$} \\
\hline 0 & 38.85 & 1774.00 & - & 41.38 & 29.25 & 28.31 \\
\hline 30 & 35.55 & 2002.70 & 1252.00 & 31.56 & 27.44 & 27.38 \\
\hline 50 & 34.10 & 1817.20 & 866.50 & 27.31 & 26.88 & 26.56 \\
\hline 70 & 33.00 & 1919.00 & 730.00 & 27.25 & 26.69 & 26.31 \\
\hline
\end{tabular}

Note. $\mathrm{SL}=$ shading levels; $\mathrm{T}$ air $=$ air temperature; ${ }^{1}$ above shading screen; ${ }^{2}$ below shading screen; ${ }^{3}$ superficial layer.

Harvest was performed 30 DAT, when plants reached the commercial harvest point. Four plot plants were selected, which were used to carry out the following evaluations: plant height $(\mathrm{cm})$ measured from soil level to leaf edge; diameter of the stem ( $\mathrm{mm}$ ) measured using a digital caliper measured on the plant stem; the number of leaves per plant was evaluated by counting, discarding yellow and/or dried leaves, from the basal leaves to the last open leaf; root length $(\mathrm{cm})$ measured with ruler graduated in $\mathrm{cm}$; Leaf area was obtained following Silva et al. (2016) by relating the dry mass of 8 leaf discs with known area $\left(1.34 \mathrm{~cm}^{2}\right)$ to the total dry mass of leaves per plant, according to the following equation: $\mathrm{LA}=(\mathrm{LDM} \times \mathrm{DLA}) / \mathrm{DDM}$. Where: $\mathrm{LA}=$ leaf $\operatorname{area}\left(\mathrm{cm}^{2}\right.$ per plant $)$; $\mathrm{LDM}=$ dry mass of the leaves $(\mathrm{g}), \mathrm{DLA}=$ leaf area of the discs $\left(\mathrm{cm}^{2}\right), \mathrm{DDM}=$ dry mass of the discs $(\mathrm{g})$.

After this stage, the different organs of the plants were separated, conditioned in Kraft paper bags and taken to dry in an oven at with forced air circulation at $65{ }^{\circ} \mathrm{C}$, for 72 hours. Next, were weighted in a precision scale, to determine the dry mass for the roots, stem and leaves and total plant $\left(\mathrm{g}\right.$ plant ${ }^{-1}$ ). The shoot-root ratio was calculated using the dry mass from the respective organs.

Soluble solids (SS) were determined with the extraction of the laves using a digital refractometer (Atago PR-100), with automatic compensation at $25^{\circ} \mathrm{C}$. Results were expressed in \%, according to methodology from AOAC (1992).

Total acidity (AT) was evaluated using a $10 \mathrm{~mL}$ aliquot of juice, in duplicate, to which $40 \mathrm{~mL}$ of distilled water and three drops of indicator alcoholic phenolphthalein $1 \%$ were added and, afterwards, proceeded by titration with a $\mathrm{NaOH} 0.1 \mathrm{~N}$ solution until the turning point, with results expressed in \% citric acid (IAL, 1985).

The potential hydrogen $(\mathrm{pH})$ was determined directly in the homogenized material using a digital potentiometer model HI 9321 (Hanna Instruments) properly calibrated (IAL, 1985).

Data were submitted to variance analysis and treatment averages were compared by Tukey test at 5\% probability, using the software SAEG 2007.

\section{Results and Discussion}

There was no significant effect in the interaction between shading levels and cultivars in the growth variables, with the exception of the shoot-root ratio. However, when isolated, the shading levels influenced the plant height, stem diameter, and root length, while cultivars differ in plant height, number of leaves and leaf area (Table 5). 
Table 5. Summary of the variance analysis for variables plant height (PH), stem diameter (SD), number of leaves $(\mathrm{NL})$, leaf area (LA), root length (RL) and shoot-root ratio (S/R) in lettuce cultivars under different shading levels. Catole do Rocha-Paraiba, Brazil, 2017

\begin{tabular}{|c|c|c|c|c|c|c|c|}
\hline \multirow{2}{*}{ Variation Sources } & \multirow{2}{*}{ DF } & \multicolumn{6}{|c|}{ Mean Squares } \\
\hline & & $\mathrm{PH}$ & SD & NL & LA & $\mathrm{RL}$ & $\mathrm{S} / \mathrm{R}$ \\
\hline Block & 3 & 4.23 & 0.02 & 10.19 & 2457.37 & 2.27 & 0.15 \\
\hline Shading (S) & 3 & $34.34^{*}$ & $0.39^{*}$ & $12.03^{\mathrm{ns}}$ & $610.27^{\mathrm{ns}}$ & $31.50^{*}$ & $3.78^{*}$ \\
\hline Error A & 9 & 11.04 & 0.12 & 9.27 & 300.78 & 1.54 & 1.28 \\
\hline Cultivars (C) & 3 & $12.05^{*}$ & $0.10^{\mathrm{ns}}$ & $151.01^{*}$ & $5833.46^{*}$ & $1.24^{\mathrm{ns}}$ & $26.12^{*}$ \\
\hline Interaction $\mathrm{S} \times \mathrm{C}$ & 9 & $1.15^{\mathrm{ns}}$ & $0.01^{\mathrm{ns}}$ & $2.29^{\mathrm{ns}}$ & $1728.88^{\mathrm{ns}}$ & $1.24^{\mathrm{ns}}$ & $5.37^{*}$ \\
\hline Error B & 36 & 2.48 & 0.05 & 8.61 & 1192.89 & 1.42 & 1.71 \\
\hline CV A $(\%)$ & - & 20.33 & 20.47 & 13.58 & 16.55 & 8.89 & 20.72 \\
\hline $\mathrm{CV} B(\%)$ & - & 9.64 & 12.74 & 13.09 & 32.95 & 8.52 & 23.92 \\
\hline
\end{tabular}

Note. $\mathrm{DF}=$ degrees of freedom; $\mathrm{CV}=$ variation coefficient; ${ }^{\mathrm{ns}}=$ not significant; ${ }^{*}=$ significant at $5 \%$ probability by F-test.

Plant height, stem diameter and root length increased in plants cultivated under the shading screens, with the highlight to $70 \%$ with values of $17.8 ; 1.99$ and 15.6 respectively (Table 6).

Table 6. Mean values for plant height (PH), stem diameter (SD), number of leaves (NL), leaf area (LA) and root length (RL) for lettuce plants as a function of shading levels and cultivars. Catole do Rocha-Paraiba, Brazil, 2017

\begin{tabular}{llllll}
\hline Shading Levels $(\%)$ & PH $(\mathrm{cm})$ & SD $(\mathrm{cm})$ & NL & LA $\left(\mathrm{cm}^{2}\right.$ plant $\left.{ }^{-1}\right)$ & RL $(\mathrm{cm})$ \\
\hline 0 & $14.50 \mathrm{~b}$ & $1.55 \mathrm{~b}$ & $21.44 \mathrm{a}$ & $103.11 \mathrm{a}$ & $12.38 \mathrm{~b}$ \\
30 & $15.90 \mathrm{ab}$ & $1.70 \mathrm{ab}$ & $22.27 \mathrm{a}$ & $107.83 \mathrm{a}$ & $13.17 \mathrm{~b}$ \\
50 & $17.00 \mathrm{ab}$ & $1.81 \mathrm{ab}$ & $22.69 \mathrm{a}$ & $110.07 \mathrm{a}$ & $14.63 \mathrm{a}$ \\
70 & $17.80 \mathrm{a}$ & $1.99 \mathrm{a}$ & $23.20 \mathrm{a}$ & $98.78 \mathrm{a}$ & $15.59 \mathrm{a}$ \\
\hline Cultivars & & & & & $13.90 \mathrm{a}$ \\
\hline 'Americana Irene' & $17.30 \mathrm{a}$ & $1.66 \mathrm{a}$ & $18.67 \mathrm{~b}$ & $136.11 \mathrm{a}$ & $14.05 \mathrm{a}$ \\
'White Boston' & $17.10 \mathrm{a}$ & $1.71 \mathrm{a}$ & $26.34 \mathrm{a}$ & $96.55 \mathrm{~b}$ & $13.39 \mathrm{a}$ \\
'Regina de Verão' & $15.50 \mathrm{~b}$ & $1.85 \mathrm{a}$ & $23.83 \mathrm{a}$ & $83.58 \mathrm{~b}$ & $14.49 \mathrm{a}$ \\
\hline
\end{tabular}

Note. The means followed by the same letter in columns do not differ at the $5 \%$ probability level by Tukey test.

These results indicate that shading screens reduced incident radiation on the plants, especially with $70 \%$, providing for greater growth of such plants. Similar results were also found in lettuce cultivated under the 30, 40 and $50 \%$ shading screens, in which increased shading provided for greater plant height (Luz et al., 2009) and stem diameter (Diamante et al., 2013; Neves et al., 2016). This fact is due to the more shaded environment receiving less radiation and presenting lower temperatures compared to open-air, providing a more favorable environment for lettuce cultivation (Ilić et al., 2017).

The 'Americana Irene' cultivar presented higher height in relation to the other cultivars, because it presented the architecture of the erect leaves. Meanwhile, the cultivar 'Green Salad Bowl', the lowest height, because it is a plant of more prone size (Table 6).

On the other hand, stem diameter and root length were not altered among the cultivars tested, regardless of the level of shading adopted. Therefore, it is possible to infer that these cultivars have a root growth pattern and the diameter are more dependent on the level of shading than on the genetic material itself.

The number of leaves was greater for cultivars 'White Boston' and 'Regina de Verão', while the leaf area was superior in 'Americana Irene' (Table 6). The number of leaves per plant is a very important factor, once indicates the adaptation of the genetic material to the environment (Diamante et al., 2013), pointing cultivars 'White Boston' and 'Regina de Verão' with better generic potential, independently from the cultivation conditions. Furthermore, the number of leaves per plant is important, once these organs are the edible part of the plant and, above all, the greater amount of leaves can alter foliar area and the production of the plant. 
According to Moraes et al. (2013), light is one of the main factors that limits vegetable development, and the leaf being the main photosynthetic organ of plants. However, in the current study, the different shading environments did not interfere with the number of leaves, as well as the foliar area. Such results demonstrate that the utilization of shading screens of up to $70 \%$ was not sufficient to alter the number of leaves and, consequently, the foliar area for lettuce cultivars. However, a trend that plants which received increased shade produced a greater amount of leaves was observed, although results were not different from cultivation in open-air.

Although the 'Americana Irene' cultivar presented smaller number of leaves, its leaf area was superior to the one observed in the other cultivars, indicating that its leaves were bigger, compensating the low number of leaves. On the other hand, cultivars 'White Boston' and 'Regina de Verão' had the greatest number of leaves, but with smaller foliar area, indicating that the increase in leaves number in these cultivars did not compensate the low foliar area, due to its smaller size. As with plant height, leaf emission and growth must be related to the genetic improvement, pointing to some cultivars with increased higher potential (Zuffo et al., 2016).

The shoot-root was greater in the 'Americana Irene' cultivar when compared to the others in all shading levels, being higher when cultivated at open-air (Table 7). For this cultivar, the shoot-root ratio is related to the leaf area and dry mass characteristics that presented the highest values, which resulted in the increase of this variable. Meanwhile, remaining cultivars did not have the shoot-root ratio altered by different shading levels. This fact reveals that the 'Americana Irene' cultivar was more efficient than other cultivars in absorbing and transferring water and nutrients to supply its nutritional and physiological needs, even with a smaller radicular system available.

Table 7. Mean values for the shoot-root ratio for lettuce plants as a function of the shading levels and cultivars. Catole do Rocha-Paraiba, Brazil, 2017

\begin{tabular}{lllll}
\hline \multirow{2}{*}{ Shading Levels (\%) } & \multicolumn{3}{c}{ Shoot-root ratio } \\
\cline { 2 - 5 } & \multicolumn{4}{c}{ Cultivars } \\
\cline { 2 - 5 } & 'Americana Irene' & 'White Boston' & 'Regina de Verão' & 'Green Salad Bowl' \\
\hline 0 & $7.56 \mathrm{Aa}$ & $3.98 \mathrm{Ba}$ & $4.88 \mathrm{BCa}$ & $5.44 \mathrm{ABa}$ \\
30 & $7.54 \mathrm{Aab}$ & $3.35 \mathrm{Ba}$ & $5.24 \mathrm{ABa}$ & $4.41 \mathrm{Ba}$ \\
50 & $5.90 \mathrm{Ab}$ & $3.24 \mathrm{Ba}$ & $5.56 \mathrm{ABa}$ & $6.56 \mathrm{Aa}$ \\
70 & $7.45 \mathrm{Aab}$ & $4.92 \mathrm{Ba}$ & $3.53 \mathrm{Ba}$ & $5.02 \mathrm{Ba}$ \\
\hline
\end{tabular}

Note. Means followed by upper case letter in the same line do not differ between cultivars and lowercase in the same column do not differ for shading at the $5 \%$ probability level by the Tukey test.

For the production variables, there was interaction between the shading levels and the cultivars only for the root dry mass. However, it was registered a significant isolated effect in the shading levels for the leaves dry mass, for the stem and total, and cultivars for leaves dry mass and stem (Table 8).

Table 8. Summary of the variance analysis for the variables for dry mass of leaves (DML), stem (DMS), root (DMR), total (SDM), pH, titratable acidity (TA) and soluble solids (SS) in lettuce cultivars under different shading levels. Catole do Rocha-Paraiba, Brazil, 2017

\begin{tabular}{lllllllll}
\hline \multirow{2}{*}{ Variation Source } & \multirow{2}{*}{ DF } & \multicolumn{9}{c}{ Mean Squares } \\
\cline { 3 - 8 } & & DML & DMS & DMR & SDM & pH & TA & SS \\
\hline Block & 3 & 0.82 & 0.00 & 0.06 & 1.33 & 0.01 & 1.38 & 0.15 \\
Shading (S) & 3 & $12.37^{*}$ & $0.62^{*}$ & $1.50^{*}$ & $29.70^{*}$ & $0.10^{*}$ & $1.27^{\text {ns }}$ & $5.13^{*}$ \\
Error A & 9 & 1.46 & 0.09 & 0.19 & 2.88 & 0.01 & 0.57 & 0.12 \\
Cultivars (C) & 3 & $5.10^{*}$ & $0.82^{*}$ & $1.55^{*}$ & $0.47^{\text {ns }}$ & $0.05^{\text {ns }}$ & $1.44^{\text {ns }}$ & $0.39^{*}$ \\
Interaction S $\times$ C & 9 & $1.63^{\text {ns }}$ & $0.12^{\text {ns }}$ & $0.35^{*}$ & $1.62^{\text {ns }}$ & $0.01^{\text {ns }}$ & 0.18 & $0.06^{\text {ns }}$ \\
Error B & 36 & 0.92 & 0.09 & 0.14 & 1.01 & 0.03 & 0.76 & 0.11 \\
CV A (\%) & - & 17.59 & 22.68 & 26.81 & 17.18 & 1.96 & 14.85 & 12.73 \\
CV B (\%) & - & 14.03 & 22.81 & 22.93 & 10.20 & 2.81 & 17.09 & 12.17
\end{tabular}

Note. $\mathrm{DF}=$ degrees of freedom; $\mathrm{CV}=$ variation coefficient; ${ }^{\mathrm{ns}}=$ not significant; ${ }^{*}=$ significant at $5 \%$ probability by F-test. 
The dry mass for leaves, stem and total was greater when lettuce plants were cultivated with 50 and $70 \%$ shading. As amongst cultivars, the leaves dry mass for 'Americana Irene' was greater and, at the same time, presented lower dry mass in the stem. The highest dry stem mass was found for the cultivar 'Green Salad Bowl' (Table 9).

Table 9. Mean values for dry mass of leaf (DML), stem (DMS), total (SDM), pH, total acidity (TA) and soluble solids (SS) in lettuce cultivars under different shading levels. Catole do Rocha-Paraiba, Brazil, 2017

\begin{tabular}{lllllll}
\hline Shading Levels (\%) & DML & DMS & SDM & pH & TA & SS \\
\hline 0 & $5.61 \mathrm{~b}$ & $1.12 \mathrm{~b}$ & $7.93 \mathrm{~b}$ & $6.17 \mathrm{~b}$ & $5.48 \mathrm{a}$ & $3.49 \mathrm{a}$ \\
30 & $6.85 \mathrm{ab}$ & $1.33 \mathrm{ab}$ & $9.97 \mathrm{a}$ & $6.27 \mathrm{ab}$ & $5.21 \mathrm{a}$ & $2.74 \mathrm{~b}$ \\
50 & $7.45 \mathrm{a}$ & $1.47 \mathrm{a}$ & $10.70 \mathrm{a}$ & $6.32 \mathrm{a}$ & $5.07 \mathrm{a}$ & $2.60 \mathrm{~b}$ \\
70 & $7.52 \mathrm{a}$ & $1.55 \mathrm{a}$ & $10.91 \mathrm{a}$ & $6.36 \mathrm{a}$ & $4.74 \mathrm{a}$ & $2.12 \mathrm{c}$ \\
\hline Cultivars & & & & & \\
\hline 'Americana Irene' & $7.91 \mathrm{a}$ & $1.05 \mathrm{c}$ & $10.21 \mathrm{a}$ & $6.20 \mathrm{a}$ & $4.61 \mathrm{a}$ & $2.55 \mathrm{~b}$ \\
'White Boston' & $6.55 \mathrm{~b}$ & $1.27 \mathrm{bc}$ & $9.95 \mathrm{a}$ & $6.33 \mathrm{a}$ & $5.22 \mathrm{a}$ & $2.91 \mathrm{a}$ \\
'Regina de Verão' & $6.40 \mathrm{~b}$ & $1.53 \mathrm{ab}$ & $9.63 \mathrm{a}$ & $6.32 \mathrm{a}$ & $5.52 \mathrm{a}$ & $2.85 \mathrm{ab}$ \\
'Green Salad Bowl' & $6.61 \mathrm{~b}$ & $1.60 \mathrm{a}$ & $9.77 \mathrm{a}$ & $6.25 \mathrm{a}$ & $5.13 \mathrm{a}$ & $2.61 \mathrm{ab}$ \\
\hline
\end{tabular}

Note. The means followed by the same letter in columns do not differ at the $5 \%$ probability level by the Tukey test.

The greatest dry mass for the different plant organs found in lettuce cultivation in shaded conditions in comparison to open-air cultivation is directly related to the greater radiation incidence in the open-air environment, possibly causing photoinhibition. Under this condition, plants had the photosynthetic process compromised, producing less dry mass (He et al., 2016). However, shading favored the reduction in air and soil temperature (Table 4), which provided for a more suitable environment for plant growth and development, considering that in high temperatures, the vegetative development of the culture is affected, due to the juvenile phase acceleration, moving prematurely to the reproductive phase with low dry mass accumulation (Sales et al., 2014). According to Taiz et al. (2017), the high temperature affects the speed of chemical reactions and internal process for solutes transportation and, consequently, the normal development of the plants.

The root dry mass was distinguished for the 'White Boston' cultivar in comparison to the other cultivars, presenting increased root dry mass in the $30 \%$ shading level. However, this behavior was repeated for cultivars in the 50 and $70 \%$ shading level (Table 10). It is important to highlight that in conditions of the greatest shading level-70\% - the 'White Boston', 'Regina de Verão' and 'Green Bowl Salad' cultivars surpassed the 'Americana Irene' cultivar, which presented the smallest root dry mass accumulation. Such results are probably due to the reduction in radiation and, consequently, lower soil temperatures promoted by the shading screen (Table 4). According to Ilić et al. (2017), shading screens have the potential to modify the amount of light, reducing radiation intensity and thermal properties of the environment, generating a more favorable microclimate to plant growth. This provided for a differentiated growth between cultivars, both for the aerial part and root, which led to larger leaf size in detriment of the root for the 'Americana Irene' cultivar.

Table 10. Mean values for root dry mass for lettuce plants under interaction between different shading levels and cultivars. Catole do Rocha-Paraiba, Brazil, 2017

\begin{tabular}{lllll}
\hline \multirow{2}{*}{ Shading Levels (\%) } & \multicolumn{3}{c}{ Root dry mass (g plant $\left.{ }^{-1}\right)$} \\
\cline { 2 - 4 } & \multicolumn{3}{c}{ Cultivars } \\
\cline { 2 - 4 } & 'Americana Irene' & 'White Boston' & 'Regina de Verão' & 'Green Salad Bowl' \\
\hline 0 & $1.25 \mathrm{Db}$ & $2.12 \mathrm{Abc}$ & $1.70 \mathrm{Bb}$ & $1.55 \mathrm{Ca}$ \\
30 & $1.23 \mathrm{Dab}$ & $2.64 \mathrm{Aa}$ & $1.51 \mathrm{Bb}$ & $1.76 \mathrm{Ca}$ \\
50 & $1.54 \mathrm{Ba}$ & $2.47 \mathrm{Aab}$ & $1.62 \mathrm{Bab}$ & $1.54 \mathrm{Ba}$ \\
70 & $1.46 \mathrm{Cab}$ & $1.88 \mathrm{Bc}$ & $2.26 \mathrm{Aa}$ & $1.76 \mathrm{Ba}$ \\
\hline
\end{tabular}

Note. Means followed by the same capital letter do not differ between cultivars within each shade level, and lowercase for shading in each cultivar at the $5 \%$ probability level by Tukey test. 
Regarding the variables for lettuce quality, no significant differences were observed for the interaction of the experimental factors shading levels and cultivars, respectively. However, there was a significant effect isolated from shade levels for $\mathrm{pH}$ and total soluble solids, and from cultivars only for soluble solids. As for total acidity, there was no statistical significant alterations between any of the factors (Table 9).

The $\mathrm{pH}$ increased while soluble solids values decreased with increasing shade levels from 0 to $70 \%$ (Table 9). The highest $\mathrm{pH}$ value was recorded when lettuce plants were grown under 50 and $70 \%$ shading in relation to the open culture. As the soluble solids decreased with increasing shading, reaching 2.12 at the shading level of $70 \%$. These results show that the $\mathrm{pH}$ of lettuce is influenced only by environmental conditions, regardless of the cultivar used.

The values for soluble solids decreased as shading increased, due to the distribution of the assimilates in the plants, with direct effect on this variable (Sales et al., 2014). In the case of lettuce cultivated under diffuse plastic light, Riga and Benedict (2017) found that soluble solids contents were lower than those found in lettuce grown under clear plastic, indicating that the leaves contained more organic acids and/or aminoacids.

Between cultivars, the soluble solids content was the greatest in the 'White Boston' cultivar and smallest in the 'Americana Irene' cultivar, independently from the shading levels (Table 9). Possibly, these results are related to the larger number of leaves also observed for the 'White Boston' cultivar in comparison to 'Americana Irene', which contributed for the increase in the photosynthetic rate, providing for greater transportation of photoassimilates and higher accumulation of sugar in leaves (Sales et al., 2014). According to Silva et al. (2011), the low soluble solids content is an important characteristic, once the consumer prefers a less sweetened lettuce, although the higher the soluble solids content, the longer the quality of the lettuce can be preserved. Thus, it is possible to indicate the 'Americana Irene' cultivar as a product with higher consumer preference, despite the reduced shelf-life.

\section{Conclusions}

The shading levels improve the lettuce plants performance in comparison to open-air cultivation, specially plant height, stem diameter, radicular length, dry mass production, $\mathrm{pH}$ and soluble solids content, being the shading of $70 \%$ the more efficient.

The 'Americana Irene' cultivar stands out regarding plant height, leaf area, leaves dry mass and soluble solids, independently from the cultivation environment. With shading, this cultivar improved the shoot-root ratio by decreasing the root dry mass.

\section{References}

Araújo Neto, S. E., Silva, E. M. N. C. P., Ferreira, R. L. F., \& Cecílio Filho, A. B. (2012). Rentabilidade da produção orgânica de alface em função do ambiente, preparo do solo e época de plantio. Revista Ciência Agronômica, 43(4), 783-791. https://doi.org/10.1590/S1806-66902012000400021

AOAC (Association of Official Analytical Chemistry). (1992). Official methods of analysis of the Association of Official Analytical Chemistry (12th ed., p. 1015). Washington: JAOAC.

Bertino, A. M. P., Mesquita, E. F., Sá, F. V. S., Cavalcante, L. F., Ferreira, N. M., Paiva, E. P., Brito, M. E. B., \& Bertino, A. M. P. (2015). Growth and gas exchange of okra under irrigation, organic fertilization and cover of soil. African Journal of Agricultural Research, 10(40), 3832-3839. https://doi.org/10.5897/ AJAR2015.9844

Bezerra Neto, F., Barros Júnior, A. P., Silva, E. O., Negreiros, M. Z., Oliveira, E. Q., Silveira, L. M., ... Nunes, G. H. S. (2006). Qualidade nutricional de cenoura e alface cultivadas em Mossoró-RN em função da densidade populacional. Horticultura Brasileira, 24(4), 476-480. https://doi.org/10.1590/S0102-05362006 000400016

Blind, A. D., \& Silva Filho, D. F. (2015). Desempenho de cultivares de alface americana cultivadas com e sem mulching em período chuvoso da Amazônia. Revista Agro@mbienteOn-line, 9(2), 143-151. https://doi.org/ 10.18227/1982-8470ragro.v9i2.2183

Diamante, M. S., Seabra Júnior, S., Inagaki, A. M., Silva, M. B., \& Dallacort, R. (2013). Produção e resistência ao pendoamento de alfaces tipo lisa cultivadas sob diferentes ambientes. Revista Ciência Agronômica, 44(1), 133-140. https://doi.org/10.1590/S1806-66902013000100017

Embrapa (Empresa Brasileira de Pesquisa Agropecuária). (1997). Centro Nacional de Pesquisa de Solos. Manual de Métodos de Análise de Solos (No. 2, p. 23). Rio de Janeiro, RJ. 
Fu, W., Li, P., \& Wu, Y. (2012). Effects of different light intensities on chlorophyll fluorescence characteristics and yield in lettuce. Scientia Horticulturae, 135(1), 45-51. https://doi.org/10.1016/j.scienta.2011.12.004

Gonçalves, E. D. V., Dartora, J., Mendoça, H. F. C., Risato, B. B., Dildey, O. D., Coltro-Roncato, S., ... Tsutsumi, C. Y. (2017). Crescimento e produtividade de cultivares de alface em ambiente protegido com e sem telas termorefletoras. Scientia Agraria Paranaensis, 16(2), 193-199.

Guerra, A. M. N. M., Costa, A. C. M., \& Tavares, P. R. F. (2017). Atividade fotossintética e produtividade de alface cultivada sob sombreamento. Revista Agropecuária Técnica, 38(3), 125-132. https://doi.org/ 10.25066/agrotec.v38i3.29246

Guimarães, M. A., Mandelli, M. S., \& Silva, D. J. H. (2011). Seleção de genótipos de Lactuca sativa L. para a produção com adubação orgânica. Revista Ceres, 58(2), 202-207. https://doi.org/10.1590/S0034-737X 2011000200011

He, J., See, X. E., Qin, L., \& Choong, T. W. (2016). Effects of Root-Zone Temperature on Photosynthesis, Productivity and Nutritional Quality of Aeroponically Grown Salad Rocket (Eruca sativa) Vegetable. American Journal of Plant Sciences, 14(7), 1993-2005. https://doi.org/10.4236/ajps.2016.714181

Ilić, S. Z., Milenković, L., Dimitrijević, A., Stanojević, L., Cvetkovićc, D., Kevrešan, Ž., ... Mastilović, J. (2017). Light modification by color nets improve quality of lettuce from summer production. Scientia Horticulturae, 226(1), 389-397. https://doi.org/10.1016/j.scienta.2017.09.009

Ilić, Z. S., \& Fallik, E. (2017). Light quality manipulation improves vegetable quality at harvest and postharvest: A review. Environmental and Experimental Botany, 139(1), 79-90. https://doi.org/10.1016/j.envexpbot. 2017.04 .006

IAF (Instituto Adolfo Lutz). (1985). Métodos químicos e físicos para análise de alimentos (3nd ed., p. 553). São Paulo, SP: Normas analíticas do Instituto Adolfo Lutz.

Kotilainen, T., Robson, T. M., \& Hernández, R. (2018). Light quality characterization under climate screens and shade nets for controlled-environment agriculture. PLoS ONE, 13(6), 1-22. https://doi.org/10.1371/ journal.pone.0199628

Luz, A. O., Seabra Júnior, S., Souza, S. B. S., \& Nascimento, A. S. (2009). Resistência ao pendoamento de genótipos de alface em ambientes de cultivo. Agrarian, 2(6), 71-82.

Moraes, L., Santos, R. K., Wisser, J. Z., \& Kreepek, R. A. (2013). Avaliação da área foliar a partir de medidas lineares simples de cinco espécies vegetais sob diferentes condições de luminosidade. Revista Brasileira Biociências, 11(4), 381-387.

Neves, F. J., Nodari, I. D. E., Seabra Junior, S., Dias, L. D. E., Silva, L. B., \& Dallacort, R. (2016). Produção de cultivares americana sob diferentes ambientes em condições tropicais. Revista Agro@mbiente On-line, 10(2), 130-136. https://doi.org/10.18227/1982-8470ragro.v10i2.3200

Pinheiro, R. R., Boscaini, R., Caron, B. O., Souza, V. Q., Meira, D., \& Schmidt, D. (2016). Lettuce seedlings production under photo-selective shading nets. International Journal of Current Research, 8(09), $37752-37756$.

Riga, P., \& Benedicto, L. (2017). Effects of light-diffusing plastic film on lettuce production and quality attributes. Spanish Journal of Agricultural Research, 15(1), 1-11. https://doi.org/10.5424/ sjar/2017151-10315

Sales, F. A. L., Barbosa Filho, J. A. D., Barbosa, J. P. R. A. D., Viana, T. V. A., \& Freitas, C. A. S. (2014). Telas agrícolas como subcobertura no cultivo de alface hidropônica. Ciência Rural, 44(10), 1755-1760. https://doi.org/10.1590/0103-8478cr20120633

Santana, M. J., Ribeiro, A. A., \& Mancin, C. A. (2016). Evapotranspiração e coeficientes de cultura para o alface e a rúcula cultivadas em Uberaba-MG. Revista Inova Ciência e Tecnologia, 2(2), 7-13.

Santi, A., Carvalho, M. A. C., Campos, O. R., Silva, A. F., Almeida, J. L., \& Monteiro, S. (2010). Ação de material orgânico sobre a produção e características comerciais de cultivares de alface. Horticultura Brasileira, 28(1), 87-90. https://doi.org/10.1590/S0102-05362010000100016

Santos, R. D, Santos, H. G., Ker, J. C., Anjos, L. H. C., \& Shimizu, S. H. (2013). Manual de descrição e coleta de solo no campo (6th ed., p. 100). Viçosa, MG: Sociedade Brasileira de Ciência do Solo.

SAEG (Sistema para Análises Estatísticas). (2007). Versão 9.1. Viçosa, MG: Fundação Arthur Bernardes/UFV. 
Silva, E. M. N. C. P., Ferreira, R. L. F., Ribeiro, A. M. A. S., Araújo Neto, S. E., \& Kusdra, J. F. (2015). Desempenho agronômico de alface orgânica influenciado pelo sombreamento, época de plantio e preparo do solo no Acre. Pesquisa Agropecuária Brasileira, 50(6), 468-474. https://doi.org/10.1590/ S0100-204X2015000600005

Silva, E. M. N. C. P., Ferreira, R. L. F., Araújo Neto, S. E., Tavella, L. B., \& Solino, A. J. S. (2011). Qualidade de alface crespa cultivada em sistema orgânico, convencional e hidropônico. Horticultura Brasileira, 29, 242-245. https://doi.org/10.1590/S0102-05362011000200019

Silva, F. A., Pereira, F. H. F. P., Campos Júnior, J. E., Nóbrega, J. S., \& Souza, W. V. (2016). Crescimento inicial do milho cultivado em solo salino e tratado com prolina. Congresso Técnico Científico da Engenharia e da Agronomia, 3.

Souza, A. L., Seabra Júnior, S., Diamante, M. S., Souza, L. H. C., \& Nunes, M. C. M. (2013). Comportamento de cultivares de alface americana sob clima tropical. Revista Caatinga, 26(4), 123-129.

Taiz, L., Zeiger, E., Moller, I. M., \& Murphy, A. (2017). Fisiologia e desenvolvimento vegetal (6th ed., p. 888). Porto Alegre, RS: Artmed.

Zoratti, L., Jaakola, L., Häggman, H. \& Giongo, L. (2015). Modification of Sunlight Radiation through colored Photo-Selective Nets Affects Anthocyanin Profile in Vaccinium spp. Berries. PLoS ONE, 10(8), 1-17. https://doi.org/10.1371/journal.pone.0135935

Zuffo, A. M., Júnior, J. M. Z., Silva, L. M. A., Silva, R. L., \& Menezes, K. O. (2016). Análise de crescimento em cultivares de alface nas condições do sul do Piauí. Revista Ceres, 63(2), 145-153. https://doi.org/ 10.1590/0034-737X201663020005

\section{Copyrights}

Copyright for this article is retained by the author(s), with first publication rights granted to the journal.

This is an open-access article distributed under the terms and conditions of the Creative Commons Attribution license (http://creativecommons.org/licenses/by/4.0/). 